

EDUCAÇÃO CIÊNCIA E SAÚDE

http://dx.doi.org/10.20438/ecs.v6i1.171

\title{
ASSISTÊNCIA DE ENFERMAGEM EM REANIMAÇÃO CARDIOPULMONAR: UMA REVISÃO INTEGRATIVA
}

\author{
Giovanna Gabrielly Custódio Macêdo ${ }^{1}$, Jéssyka Samara de Oliveira Macedo ${ }^{1}$, \\ Karla Karolline Barreto Cardins ${ }^{2}$ \\ ${ }^{1}$ Discente do curso de Bacharelado em Enfermagem, Unidade Acadêmica de Enfermagem, \\ Centro de Educação e Saúde, Universidade Federal de Campina Grande. Cuité, Paraíba, \\ Brasil. \\ 2 Docente do curso de Bacharelado em Enfermagem, Unidade Acadêmica de Enfermagem, \\ Centro de Educação e Saúde, Universidade Federal de Campina Grande. Cuité, Paraíba, \\ Brasil.
}

E-mail para correspondência: cmacedogiovanna@hotmail.com

\begin{abstract}
Resumo
Considerando que a competência e a habilidade do profissional de enfermagem ao paciente em parada cardiorrespiratória determinará a sobrevida e/ou a qualidade de vida do indivíduo, assim como a sua possibilidade de ocorrência em todos os setores de saúde, propõe-se como objetivo dessa revisão integrativa analisar o cenário da assistência de enfermagem em reanimação cardiopulmonar no Brasil a partir das perspectivas atuais das publicações científicas. Realizou-se o cruzamento dos descritores "Reanimação Cardiopulmonar, "Cuidados de Enfermagem" e "Enfermagem em Emergência", a partir do operador booleano AND nas bases de dados BDEnf, LILACS e SciELO. Após filtração da amostra inicial de 23 artigos por meio de critérios de inclusão e exclusão, o corpus de análise da pesquisa foi composto por 6 artigos. A discussão em análise temática dos artigos resultou na construção de duas categorias: Condicionantes da qualidade da Reanimação Cardiopulmonar e Intervenções que antecedem, perpassam e transcedem a Reanimação Cardiopulmonar. Conclui-se que apesar da relevância do profissional de enfermagem na efetividade da Reanimação Cardiopulmonar, desde o aprimoramento pessoal e da equipe aos cuidados propriamente ditos, a enfermagem ainda mantém uma atuação limitada na área de urgência e emergência.
\end{abstract}

Palavras-chave: Reanimação Cardiopulmonar, Cuidados de Enfermagem, Enfermagem em Emergência.

\begin{abstract}
Considering that the competence and the ability of the nursing professional to the patient in heart arrest will determine the survival and / or quality of life of the individual, as well as their possibility of occurrence in all health sectors, it is proposed as an objective of this integrative review to analyze the scenario of nursing care in cardiopulmonary resuscitation in Brazil from the current perspectives of scientific publications. The descriptors "Cardiopulmonary
\end{abstract}


Resuscitation," "Nursing Care" and "Emergency Nursing" were cross-referenced from the Boolean operator AND in the databases BDEnf, LILACS and SciELO. After filtering the initial sample of 23 articles by means of inclusion and exclusion criteria, the corpus of analysis of the research was composed of 6 articles. The discussion in thematic analysis of the articles resulted in the construction of two categories: Cardiopulmonary Resuscitation quality factors and Interventions that precedes, pass through and transcend Cardiopulmonary Resuscitation. It is concluded that despite the relevance of the nursing professional in the effectiveness of the Cardiopulmonary Resuscitation, from the personal improvement and the team to the proper care, the nursing still has a limited performance in the area of urgency and emergency.

Keywords: Cardiopulmonary Resuscitation, Nursing Care, Emergency Nursing.

\section{Introdução}

A reaminação cardiopulmonar (RCP) consiste em um conjunto de técnicas aplicadas à vítima em situação de parada cardiorrespiratória (PCR). A PCR é caracterizada por ausência no bombeamento e cessação das incurssões respiratórias. A parada cardíaca pode ser identificada principalmente por ausência de batimentos cardíacos e pulso numa grande artéria, além da possibilidade de dilatação das pupilas, uma vez que a midríase se apresenta como sinal de mau prognóstico, já que seu inicío se dá 45 segundos após a interrupção do aporte sanguíneo para o cérebro; enquanto a parada respiratória é visualizada por meio ausência de expansibilidade torácica (AMERICAN HEART ASSOCIATION, 2015; BRASIL, 2016).

As vítimas em PCR também poderão apresentar atividade semelhante a convulsão ou gasping. O gasping nessa situação é acompanhado da ausência de resposta verbal. Além disso, há possibilidade ainda de espasmo laríngeo e cianose central (AMERICAN HEART ASSOCIATION, 2015).

Estima-se que no Brasil ocorram cerca de 630 mil mortes súbitas por ano decorrentes de arritmias cardíacas e infartos agudos do miocárdio, tendo a PCR prevalência de aproximadamente 200.000 vítimas ao ano e distribuição de metade dos casos em ambiente intra-hospitalar e a outra metade em ambiente extra-hospitalar (SILVA et al, 2017; GONZALES et al, 2013). Uma rápida, precisa e resolutiva intervenção aumenta as possibilidades de sobrevida da vítima por restaurar com eficácia a função cardiopulmonar, além de diminuir graves danos ao tecido cerebral por anóxia (SILVA et al, 2017; TODESCATO, 2017). 
De maneira geral, a etiologia da PCR pode ser classificada em primária ou secundária. A primária engloba situações, geralmente não traumáticas, em que a parada se deu por condições fisiológicas do coração que determinaram arritmias cardíacas. Falhas cardíacas dessa natureza em sua maioria associam-se à isquemia tecidual por fatores de base. A PCR secundária inclui disfunções respiratórias e fatores externos sobre o coração (AMERICAN HEART ASSOCIATION, 2015).

Sabendo que a necessidade de RCP é passível de ocorrer em todos os setores de saúde e considerando a Lei $\mathrm{n}^{0}$ 7.498/86, que dispõe sobre 0 exercício profissional da enfermagem, é de competência do enfermeiro a elaboração e implementação de um plano de cuidados em enfermagem que permeie uma assistência eficaz e mínima em sequelas ao paciente em risco de morte. Dessa forma, cabe a ele reconhecer a iminência ou ocorrência do evento e, subsequentemente, executar a RCP, o que exige impreterível conhecimento teórico-científico (BRASIL, 1986).

Nessa perspectiva, ao considerar que a competência e habilidade do profissional de enfermagem na prestação do atendimento determinará a sobrevida e, em muitas situações, a qualidade de vida do indivíduo em PCR, além de compreender também a responsabilidade desse profissional como um dos eixos prioritários do cuidado em emergências, objetiva-se analisar 0 cenário da assistência de enfermagem em reanimação cardiopulmonar no Brasil a partir das perspectivas atuais das publicações científicas.

\section{Metodologia}

A investigação desenvolvida é do tipo revisão integrativa da literatura. Assim, seguiram-se as seis fases recomendadas pela literatura para revisões integrativas: questionamento da revisão integrativa; busca na literatura; categorização dos estudos; avaliação dos estudos incluídos na revisão; interpretação dos resultados; e síntese do conhecimento evidenciado nos artigos analisados (POMPEO; ROSSI; GALVÃO, 2009).

A pesquisa foi realizada durante o mês de junho de 2018, por meio de uma busca nos periódicos indexados, por dois revisores/avaliadores 
independentes, através das bases de dados Base de Dados de Enfermagem (BDEnf), Literatura Latino-Americana e do Caribe em Ciências da Saúde (LILACS) e Scientific Eletronic Library Online (SciELO).

Utilizou-se o cruzamento por meio do operador booleano AND dos descritores "Reanimação Cardiopulmonar", "Cuidados de Enfermagem" e "Enfermagem em Emergência" pré-estabelecidos pelo Descritores de Ciências da Saúde (DeCS).

Para aglomerar o maior número de artigos que pudessem responder ao questionamento "Qual o cenário da assistência de enfermagem em RCP no Brasil?", implementou-se duas estratégias de busca: 1. Cruzamento por descritores; 2. Revisão da bibliografia dos artigos selecionados. Foram incluídos artigos científicos indexados nos idiomas português, inglês e espanhol, que versam sobre a assistência de enfermagem em RCP no Brasil, sendo trabalhos originais ou de revisão relevantes para o tema, disponíveis na íntegra via internet, de forma gratuita, no período de 2013 a 2018.

O cruzamento em trio resultou em uma amostra inicial de 23 artigos, de maneira que 12 foram obtidos na BDEnf, 11 na LILACS e 0 na SciELO. Em seguida, procedeu-se a leitura dos títulos e resumos dos artigos identificados, dentre os quais, foram excluídos artigos não disponíveis na íntegra, componentes de literatura cinzenta, como manuais e livros, e artigos repetidos. Dessa forma, formou-se uma amostra de 6 artigos.

\section{Resultados e discussão}

Após filtração da amostra inicial por meio dos critérios de inclusão e exclusão, o corpus de análise foi composto por 6 artigos, com obtenção de 3 na BDEnf, 3 LILACS e nenhum na SciELO. A maior parte das exclusões ocorreu em virtude dos artigos não terem publicação em periódicos brasileiros e de o seu tempo de publicação ser superior ao exigido nos critérios de inclusão.

A maioria das publicações se concentrou no ano de 2015 (50\%), ao passo que os anos 2013, 2016 e 2018 apresentaram somente 1 publicação. No delineamento metodológico, 5 artigos adotaram métodos de pesquisas de campo e apenas 1 de revisão integrativa. 
De maneira a subsidiar a análise fidedigna dos artigos, caracterizou-se o corpus da pesquisa conforme informações da autoria, publicação e pesquisa. $O$ quadro 1 a seguir sistematiza as principais informações:

Quadro 1: Sistematização do corpus de análise da pesquisa

\begin{tabular}{|c|c|c|c|c|c|}
\hline $\begin{array}{l}\text { Autor, ano } \\
\text { de } \\
\text { publicação }\end{array}$ & $\begin{array}{l}\text { Título do } \\
\text { artigo }\end{array}$ & $\begin{array}{l}\text { Objetivo(s) do } \\
\text { estudo }\end{array}$ & $\begin{array}{l}\text { Local e } \\
\text { ano do } \\
\text { estudo }\end{array}$ & Métodos & Desfecho \\
\hline $\begin{array}{l}\text { PINHEIRO; } \\
\text { SANTOS } \\
\text { JÚNIOR; } \\
\text { PINHEIRO, } \\
2018\end{array}$ & $\begin{array}{l}\text { Parada } \\
\text { cardiorrespirató } \\
\text { ria: vigilância, } \\
\text { prevenção e } \\
\text { cuidados após } \\
\text { PCR }\end{array}$ & $\begin{array}{l}\text { Reunir } \\
\text { produções } \\
\text { científicas } \\
\text { acerca de } \\
\text { ações de } \\
\text { vigilância, } \\
\text { prevenção e os } \\
\text { cuidados de } \\
\text { enfermagem } \\
\text { na parada } \\
\text { cardiorrespirat } \\
\text { ória }\end{array}$ & $\begin{array}{l}\text { Meio } \\
\text { eletrônic } \\
\text { o, } 2016\end{array}$ & $\begin{array}{l}\text { Revisão } \\
\text { integrativa } \\
\text { da literatura }\end{array}$ & $\begin{array}{l}\text { A enfermagem é } \\
\text { essencial na } \\
\text { identificação de } \\
\text { fatores } \\
\text { predispondentes } \\
\text { da PCR e } \\
\text { reconhecimento } \\
\text { de sua } \\
\text { necessidade; é } \\
\text { peça chave na } \\
\text { delegação de } \\
\text { atribuições aos } \\
\text { demais membros } \\
\text { da equipe; } \\
\text { auxiliam o } \\
\text { médico na } \\
\text { realização da } \\
\text { RCP; e prestam } \\
\text { cuidadodos após a } \\
\text { RCP }\end{array}$ \\
\hline $\begin{array}{l}\text { SILVA; } \\
\text { MACHADO, } \\
2013\end{array}$ & $\begin{array}{l}\text { Elaboração de } \\
\text { guia teórico de } \\
\text { atendimento em } \\
\text { parada } \\
\text { cardiorrespirató } \\
\text { ria para } \\
\text { enfermeiros }\end{array}$ & $\begin{array}{l}\text { Identificar o } \\
\text { conhecimento } \\
\text { de enfermeiros } \\
\text { de hospital do } \\
\text { Vale do } \\
\text { Paraíba, São } \\
\text { Paulo, Brasil, } \\
\text { sobre a parada } \\
\text { cardiorrespirat } \\
\text { ória e elaborar } \\
\text { um guia teórico } \\
\text { para o } \\
\text { atendimento } \\
\text { nesta } \\
\text { emergência }\end{array}$ & $\begin{array}{l}\text { Hospital } \\
\text { filantrópi } \\
\text { co de } \\
\text { Guaratin } \\
\text { guetá, } \\
2012\end{array}$ & $\begin{array}{l}\text { Estudo } \\
\text { metodológi } \\
\text { co }\end{array}$ & $\begin{array}{l}\text { Foram } \\
\text { identificadas } \\
\text { limitações no } \\
\text { conhecimento } \\
\text { dos enfermeiros } \\
\text { sobre a temática. } \\
\text { Diante disso foi } \\
\text { criado um guia } \\
\text { teórico para o } \\
\text { atendimento à } \\
\text { parada } \\
\text { cardiorrespiratóri } \\
\text { a, contemplando } \\
\text { as dúvidas } \\
\text { apresentadas }\end{array}$ \\
\hline $\begin{array}{l}\text { CITOLINO } \\
\text { FILHO et al, } \\
2015\end{array}$ & $\begin{array}{l}\text { Fatores que } \\
\text { comprometem a } \\
\text { qualidade da } \\
\text { ressuscitação } \\
\text { cardiopulmonar } \\
\text { em unidades de } \\
\text { internação: } \\
\text { percepção do } \\
\text { enfermeiro }\end{array}$ & $\begin{array}{l}\text { Identificar, na } \\
\text { percepção dos } \\
\text { enfermeiros, os } \\
\text { fatores que } \\
\text { comprometem } \\
\text { a qualidade da } \\
\text { assistência } \\
\text { prestada } \\
\text { durante o } \\
\text { atendimento do } \\
\text { paciente em } \\
\text { PCR em } \\
\text { unidades de }\end{array}$ & $\begin{array}{l}\text { Instituto } \\
\text { do } \\
\text { Coração } \\
\text { do } \\
\text { Hospital } \\
\text { das } \\
\text { Clínicas } \\
\text { da } \\
\text { Faculda } \\
\text { de de } \\
\text { Medicin } \\
\text { a da } \\
\text { Universi }\end{array}$ & $\begin{array}{l}\text { Estudo } \\
\text { descritivo, } \\
\text { exploratório }\end{array}$ & $\begin{array}{l}\text { A identificação } \\
\text { dos fatores que } \\
\text { comprometem a } \\
\text { qualidade da } \\
\text { RCP, na } \\
\text { percepção dos } \\
\text { enfermeiros, } \\
\text { serve de } \\
\text { parâmetro para } \\
\text { implantação de } \\
\text { melhorias e de } \\
\text { capacitação das } \\
\text { equipes que }\end{array}$ \\
\hline
\end{tabular}




\begin{tabular}{|c|c|c|c|c|c|}
\hline $\begin{array}{l}\text { MEKITARIA } \\
\text { N; ANGELO, } \\
2015\end{array}$ & $\begin{array}{l}\text { Presença da } \\
\text { família em sala } \\
\text { de emergência } \\
\text { pediátrica: } \\
\text { opiniões dos } \\
\text { profissionais de } \\
\text { saúde }\end{array}$ & $\begin{array}{l}\text { Conhecer as } \\
\text { opiniões de } \\
\text { profissionais } \\
\text { de saúde em } \\
\text { relação à } \\
\text { presença da } \\
\text { família durante } \\
\text { o atendimento } \\
\text { em sala de } \\
\text { emergência } \\
\text { pediátrica }\end{array}$ & $\begin{array}{l}\text { Pronto- } \\
\text { socorro } \\
\text { infantil } \\
\text { do } \\
\text { Hospital } \\
\text { Universi } \\
\text { tário da } \\
\text { Universi } \\
\text { dade de } \\
\text { São } \\
\text { Paulo, } \\
2012\end{array}$ & $\begin{array}{l}\text { Estudo } \\
\text { transversal }\end{array}$ & $\begin{array}{l}\text { Para permitir a } \\
\text { presença da } \\
\text { família em sala } \\
\text { de emergência, é } \\
\text { necessário } \\
\text { sensibilizar } \\
\text { profissionais de } \\
\text { saúde, } \\
\text { especialmente a } \\
\text { equipe de } \\
\text { enfermagem e os } \\
\text { profissionais } \\
\text { formados há mais } \\
\text { tempo, que são } \\
\text { mais resistentes } \\
\text { a permitir que a } \\
\text { família fique ao } \\
\text { lado da criança } \\
\text { durante o } \\
\text { atendimento de } \\
\text { emergência }\end{array}$ \\
\hline $\begin{array}{l}\text { LISBOA; } \\
\text { BORGES; } \\
\text { MONTEIRO, } \\
2016\end{array}$ & $\begin{array}{l}\text { Avaliação do } \\
\text { conhecimento } \\
\text { dos enfermeiros } \\
\text { sobre os } \\
\text { cuidados pós- } \\
\text { parada } \\
\text { cardiorrespirató } \\
\text { ria }\end{array}$ & $\begin{array}{l}\text { Avaliar o } \\
\text { conhecimento } \\
\text { dos } \\
\text { enfermeiros } \\
\text { que atuam nas } \\
\text { unidades de } \\
\text { emergência de } \\
\text { hospitais } \\
\text { públicos } \\
\text { acerca dos } \\
\text { cuidados pós- } \\
\text { pararada } \\
\text { cardiorrespirat } \\
\text { ória }\end{array}$ & $\begin{array}{l}\text { Unidade } \\
\text { s de } \\
\text { pronto } \\
\text { socorro } \\
\text { do } \\
\text { Distríto } \\
\text { Federal, } \\
2013\end{array}$ & $\begin{array}{l}\text { Estudo } \\
\text { descritivo } \\
\text { qualitativo }\end{array}$ & $\begin{array}{l}\text { Os enfermeiros } \\
\text { apresentaram } \\
\text { conhecimento } \\
\text { insatisfatório } \\
\text { sobre cuidados } \\
\text { pós-parada } \\
\text { cardiorrespiratóri } \\
\text { a }\end{array}$ \\
\hline $\begin{array}{l}\mathrm{KOCHHAN} \\
\text { et al, } 2015 .\end{array}$ & $\begin{array}{l}\text { Parada } \\
\text { cardiorrespirató } \\
\text { ria e manobras } \\
\text { de } \\
\text { ressuscitação } \\
\text { na ótica de } \\
\text { enfermeiros de } \\
\text { um pronto } \\
\text { socorro }\end{array}$ & $\begin{array}{l}\text { Conhecer o } \\
\text { domínio teórico } \\
\text { dos } \\
\text { enfermeiros de } \\
\text { um hospital de } \\
\text { pronto socorro } \\
\text { quanto à } \\
\text { identificação } \\
\text { da parada } \\
\text { cardiorrespirat } \\
\text { ória e as } \\
\text { manobras de } \\
\text { ressuscitação }\end{array}$ & $\begin{array}{l}\text { Unidade } \\
\text { s de } \\
\text { terapia } \\
\text { intensiv } \\
\text { a e } \\
\text { emergê } \\
\text { ncia de } \\
\text { um } \\
\text { hospital } \\
\text { de Porto } \\
\text { Alegre, } \\
\text { Rio } \\
\text { Grande }\end{array}$ & $\begin{array}{l}\text { Estudo } \\
\text { descritivo } \\
\text { exploratório } \\
\text { quantitativo }\end{array}$ & $\begin{array}{l}\text { Evidenciou-se a } \\
\text { necessidade de } \\
\text { atualização dos } \\
\text { enfermeiros } \\
\text { entrevistados } \\
\text { sobre } \\
\text { procedimentos de } \\
\text { ressuscitação }\end{array}$ \\
\hline
\end{tabular}

$\begin{array}{ll}\text { internação } & \text { dade de } \\ \text { hospitalar e } & \text { São } \\ \text { analisar a } & \text { Paulo, } \\ \text { influência do } & 2014 \\ \text { turno de } & \\ \text { trabalho e do } & \\ \text { tempo de } & \\ \text { experiência } & \\ \text { dos } & \\ \text { profissionais } & \\ \text { na percepção } & \\ \text { destes fatores } & \\ \text { Conhecer as } & \text { Pronto- } \\ \text { opiniões de } & \text { socorro } \\ \text { profissionais } & \text { infantil } \\ \text { de saúde em } & \text { do } \\ \text { relação à } & \text { Hospital } \\ \text { presença da } & \text { Universi } \\ \text { família durante } & \text { tário da } \\ \text { o atendimento } & \text { Universi } \\ \text { em sala de } & \text { dade de } \\ \text { emergência } & \text { São } \\ \text { pediátrica } & \text { Paulo, } \\ & \text { 2012 }\end{array}$

enfermeiros

que atuam nas

hospitais

públicos

acerca dos

cuidados pós-

ória

dos

enfermeiros de

um hospital de

to socorro

quanto à

cardiorrespirat

manobras de

Grande atuam em

unidades de

internação enfermagem e os formados há mais tempo, que são mais resistentes durante 0 atendimento de nergência apresentaram conhecimento pós-parada cardiorrespiratóri a

Evidenciou-se a ecessidade de enfermeiros entrevistados sobre procedimentos de essuscitação 


$\begin{array}{ll}\text { preconizadas } & \text { do Sul, } \\ \text { pelas diretrizes } & 2014 \\ \text { da American } & \\ \text { Heart } & \\ \text { Association de } \\ 2010\end{array}$

A discussão da pesquisa seguiu o procedimento de análise temática, constituída pelas etapas de pré-análise, categorização do material, disposição dos dados nas categorias e interpretação das informações (MINAYO, 2007). A assistência de enfermagem na RCP apresentou-se estruturada a partir da análise de fatores que condicionam a qualidade da RCP e das intervenções em $\mathrm{RCP}$, que incluem cuidados pré, intra e pós-reanimação. O quadro 2 apresenta as categorias formuladas a partir da análise temática do corpus:

Quadro 2: Categorização dos dados conforme análise temática

\begin{tabular}{|c|c|c|}
\hline Categoria & Título do artigo & $\begin{array}{l}\text { Autores e ano } \\
\text { de publicação }\end{array}$ \\
\hline \multirow[t]{3}{*}{$\begin{array}{l}\text { Condicionantes da qualidade } \\
\text { da RCP }\end{array}$} & $\begin{array}{l}\text { Fatores que comprometem a qualidade da } \\
\text { ressuscitação cardiopulmonar em unidades } \\
\text { de internação: percepção do enfermeiro }\end{array}$ & $\begin{array}{l}\text { CITOLINO } \\
\text { FILHO, C. M., } \\
\text { et al., } 2015\end{array}$ \\
\hline & $\begin{array}{l}\text { Presença da família em sala de emergência } \\
\text { pediátrica: opiniões dos profissionais de } \\
\text { saúde }\end{array}$ & $\begin{array}{l}\text { MEKITARIAN, } \\
\text { F. F. P.; } \\
\text { ANGELO, M., } \\
2015\end{array}$ \\
\hline & $\begin{array}{l}\text { Elaboração de guia teórico de atendimento } \\
\text { em parada cardiorrespiratória para } \\
\text { enfermeiros }\end{array}$ & $\begin{array}{l}\text { SILVA, A. B.; } \\
\text { MACHADO, R. } \\
\text { C., } 2013\end{array}$ \\
\hline \multirow[t]{3}{*}{$\begin{array}{l}\text { Intervenções que antecedem, } \\
\text { perpassam e transcedem a } \\
\text { RCP }\end{array}$} & $\begin{array}{l}\text { Parada cardiorrespiratória: vigilância, } \\
\text { prevenção e cuidados após PCR }\end{array}$ & $\begin{array}{l}\text { PINHEIRO, D. } \\
\text { B. S.; SANTOS } \\
\text { JÚNIOR, E.B.; } \\
\text { PINHEIRO, L. } \\
\text { S. B., } 2018\end{array}$ \\
\hline & $\begin{array}{l}\text { Avaliação do conhecimento dos enfermeiros } \\
\text { sobre os cuidados pós-parada } \\
\text { cardiorrespiratória }\end{array}$ & $\begin{array}{l}\text { LISBOA, N. S.; } \\
\text { BORGES, M. } \\
\text { S.; } \\
\text { MONTEIRO, P. } \\
\text { S., } 2016\end{array}$ \\
\hline & $\begin{array}{l}\text { Parada cardiorrespiratória e manobras de } \\
\text { ressuscitação na ótica de enfermeiros de um } \\
\text { pronto socorro } \\
\text { Elaboração de guia teórico de atendimento } \\
\text { em parada cardiorrespiratória para } \\
\text { enfermeiros }\end{array}$ & $\begin{array}{l}\text { KOCHHAN, S. } \\
\text { l. et al., } 2015 \\
\text { SILVA, A. B.; } \\
\text { MACHADO, R. } \\
\text { C., } 2013\end{array}$ \\
\hline
\end{tabular}




\section{Categoria 1: Condicionantes da qualidade da RCP}

Um estudo realizado em um centro de referência em doenças cardiopulmonares de São Paulo apontou os seguintes condicionantes negativos da qualidade da RCP: elevado número de profissionais no cenário, falta de harmonia entre a equipe e/ou estresse pessoal de algum membro, falta de material e/ou falha de equipamento, pouco domínio na manipulação do carrinho de parada e presença de familiar no início do atendimento (CITOLINO FILHO et al, 2015).

Além dos fatores citados acima, Mekitarian e Angelo (2015) afirmam que a presença dos familiares durante a realização da RCP foi desaprovada pelos profissionais de enfermagem de uma emergência pediátrica de São Paulo, em virtude das repercussões psicológicas do momento e da impossibilidade da família de prestar cuidados, deixando-a impotente diante da exigência da situação.

Em contrapartida, Citolino Filho et al (2015) relatam que o contínuo investimento em treinamentos, certificação em cursos de suporte avançado de vida e implantação de protocolos de reanimação desempenham interferência positiva na redução das taxas de mortalidade, da necessidade de transferência para unidade de terapia intensiva após a PCR e do quantitativo de pacientes com instabilidade clínica que evoluem para PCR.

Em consoante a isso, Silva e Machado (2013) afirmam que o nível de preparo em RCP e a sensibilização da necessidade de aprimoramento também devem ser considerados como características individuais que condiciam o procedimento.

Apesar disso, os autores desse estudo, realizado em hospital filantrópico de São Paulo, constataram que $40 \%$ dos profissionais não sabiam reconhecer as manifestações clínicas da PCR e $78 \%$ não souberam responder quais os fármacos a serem utilizados na RCP, enquanto $88 \%$ não sabiam definir o aprazamento para administração, apesar de 93\% dos participantes se considerarem aptos a realizar a RCP. Além disso, nenhum enfermeiro descreveu corretamente a manobra de compressão torácica (SILVA; MACHADO, 2013). 


\section{Categoria 2: Intervenções que antecedem, perpassam e transcendem a RCP}

Pinheiro, Santos Júnior e Pinheiro (2018) apontam que tão necessários quanto os cuidados na PCR propriamente dita são aqueles prestados antes de sua ocorrência. Assim, tendo em vista a liderança em enfermagem, é necessário que o enfermeiro forneça subsídios para a capacitação da equipe e para a administração da situação, de maneira que todos estejam aptos a reconhecer a PCR e executar a RCP de maneira eficaz.

Ao compreender a necessidade do desempenho de atividades gerenciais, das quais destaca-se nesse contexto $o$ aprimoramento da equipe e a produção de materiais para suporte teórico, a assistência de enfermagem em RCP também se estende à construção de padrões assistenciais para a reanimação.

A partir dessa perspectiva, Silva e Machado (2013) apontam que a construção de um guia que baseie o aperfeiçoamento e a padronização da RCP colaboram com um melhor desempenho da equipe. Os autores traçam como medidas de atendimento sequenciais: I) reconhecer a PCR; II) chamar ajuda; III) confirmar pulso; IV) iniciar RCP; V) abrir via aérea e aplicar duas ventilações de resgaste; VI) avaliar ritmo cardíaco; e VII) iniciar terapia medicamentosa.

Além do aprimoramento da equipe, Pinheiro, Santos Júnior e Pinheiro (2018) relatam também que a relevância do enfermeiro no período antes da PCR se dá, concomitantemente, na manutenção e distribuição dos materiais contidos no carrinho de emergência.

Kochhan et al (2015) e Pinheiro, Santos Júnior e Pinheiro (2018) corroboram que na iminência da PCR as atribuições pertinentes à enfermagem incluem: monitorar e identificar padrões ou ausência do rítmo cardíaco e iniciar as manobras de Suporte Básico de Vida (SBV), além de auxiliar nos procedimentos de Suporte Avançado de Vida (SAV) e na desfibrilação precoce.

Lisboa, Borges e Monteiro (2016) destacam como atividades importantes do profissional de enfermagem a avaliação constante do estado hemodinâmico por meio da mensuração da pressão; a otimização do suporte ventilatório com 
o objetivo de garantir oxigenação, perfusão dos órgãos e evitar a hipóxia e hiperóxia; a avaliação do nível de consciência e de sedação, bem como da reação pupilar, das funções motoras e dos sinais vitais para prevenir lesões cerebrais por hipóxia do tecido nervoso; e atentar para que no processo de termorregulação se evite a febre e hipotermia terapêutica seja aplicada quando possível e indicada.

À posteriori, cabe à enfermagem registrar as informações inerentes ao estado de saúde do paciente e as ações realizadas, como também o fornecimento de orientações e suporte psicológico à família que pode estar em sofrimento (PINHEIRO; SANTOS JÚNIOR; PINHEIRO, 2018).

Ao considerar que cerca de $50 \%$ dos pacientes sobreviventes à PCR não alcançam o $30^{\circ}$ dia de vida, entende-se a importância dos cuidados pós-RCP. Neste período é importante que o enfermeiro e toda a equipe de saúde tenham conhecimento das consequências da PCR, das quais destacam-se lesão cerebral, disfunção miocárdica e resposta sistêmica à isquemia/reperfusão. Segundo Lisboa, Borges e Monteiro (2016), com a finalidade de reverter esses mecanismos, além de eliminar os fatores causais da PCR, o enfermeiro deve otimizar os suportes hemodinâmico, respiratório, neurológico e térmico.

\section{Conclusão}

$\mathrm{O}$ atual cenário assistencial exige que, mais que efetivar a $\mathrm{RCP}$, o enfermeiro reconheça fatores individuais e ambientais que condicionam o procedimento, assim como saiba identificar fragilidades pessoais que possam prejudicar seu cuidado.

Apesar da maiora dos profissionais de enfermagem compreenderem a possibilidade de ocorrência de uma PCR em todos os setores de saúde, assim como a necessidade de uma intervenção rápida e resolutiva para que se proporcione melhores chances de sobrevida ao paciente, a enfermagem ainda mantém uma atuação limitada na área de urgência e emergência.

Esse cenário foi afirmado pelo reduzido número de publicações científicas obtidas nesse estudo. De maneira a considerarmos que a produção científica 
corrobora com o aperfeiçoamento prático dos profissionais e com melhores métodos assistenciais, entendemos que a enfermagem permanece desatualizada e pouco resolutiva nessa perspectiva.

Contudo, constatou-se que embora o quantitativo de publicações tenha sido pequeno, os artigos obtidos apresentaram discussões pertinentes para a melhoria assistencial dos profissionais.

\section{Referências}

AMERICAN HEART ASSOCIATION. Guidelines 2015 CPR \& ECC. Atualização das Diretrizes de RCP e ACE. 2015. Disponível em: https://eccguidelines.heart.org/wp-content/uploads/2015/10/2015-AHAGuidelines-Highlights-Portuguese.pdf. Acesso em: 09 jun. 2018.

BRASIL. Lei $n^{\circ} 7.498$ de 25 de junho de 1986. Dispõe sobre a regulamentação do exercício da enfermagem, e dá outras providências. Diário Oficial [da] República Federativa do Brasil. Brasília, DF, 25 jul. 1986. Disponível em: http://www.planalto.gov.br/ccivil_03/Leis/L7498.htm. Acesso em: 09 de jun. 2018.

BRASIL. Ministério da Saúde. Secretaria de Atenção à Saúde. Protocolos de Intervenção para o SAMU 192: Serviço de Atendimento Móvel de Urgência. 2. ed. Brasília: Ministério da Saúde, 2016.

CITOLINO FILHO, Clairton Marcos, et al. Fatores que comprometem a qualidade da ressuscitação cardiopulmonar em unidades de internação: percepção do enfermeiro. Rev Esc Enferm USP, v.49, n.6, p.908-914, 2015. Disponível em: http://www.scielo.br/pdf/reeusp/v49n6/pt_0080-6234-reeusp-4906-0908.pdf. Acesso em: 12 jun. 2018.

GONZALEZ, Maria Margarita, et al. I Diretriz de Ressuscitação Cardiopulmonar e Cuidados Cardiovasculares de Emergência da Sociedade Brasileira de Cardiologia: Resumo Executivo. Arq Bras Cardiol, v.100, n.2, p.105-113, 2013. Disponível em:

http://www.arquivosonline.com.br/2013/10002/pdf/interativa-10002.pdf. Acesso em: 09 jun. 2018.

KOCHHAN, Sabrina Ines, et al. Parada cardiorrespiratória e manobras de ressuscitação na ótica de enfermeiros de um pronto socorro. Rev Enferm UFPI, v. 4, n. 1, p. 54-60, 2015. Disponível em:

http://www.ojs.ufpi.br/index.php/reufpi/article/view/2064/pdf. Acesso em: 13 jun. 2018. 
LISBOA, Nayara da Silva; BORGES, Moema da Silva; MONTEIRO, Pedro Sadi. Avaliação do conhecimento dos enfermeiros sobre cuidados pós-parada cardiorrespiratória. Rev enferm UFPE on line, v. 10, n.10, p. 3778-3786, 2016. Disponível em:

https://periodicos.ufpe.br/revistas/revistaenfermagem/article/view/11443/13255. Acesso em: 13 jun. 2018.

MEKITARIAN, Francine Fernandes Pires; ANGELO, Margareth. Presença da família em sala de emergência pediátrica: opiniões dos profissionais de saúde. Rev Paul Pediatr, v.33, n.4, p.460-466, 2015. Disponível em: http://www.scielo.br/pdf/rpp/v33n4/pt_0103-0582-rpp-33-04-0460.pdf. Acesso em: 12 jun. 2018.

MINAYO, Maria Cecília de Souza. O desafio do conhecimento: pesquisa qualitativa em saúde. 10. ed. São Paulo: HUCITEC, 2007.

PINHEIRO, Diego Bruno Santos; SANTOS JÚNIOR, Edson Batista; PINHEIRO, Liliane de Sousa Borges. Parada cardiorrespiratória: vigilância, prevenção e cuidados após PCR. Rev pesqui cuid fundam (Online), v.10, n.2, p.577-584, 2018. Disponível em:

http://www.seer.unirio.br/index.php/cuidadofundamental/article/view/6489/pdf_1 . Acesso em: 12 jun. 2018.

POMPEO, Daniele Alcalá; ROSSI, Lídia Aparecida; GALVÃO, Cristina Maria. Integrative literature review: the initial step in the validation process of nursing diagnoses. Acta Paul Enferm, v.22, n.4, p.434-8, 2009. Disponível em: http://www.scielo.br/pdf/ape/v22n4/en_a14v22n4.pdf. Acesso em: 04 set. 2018.

SILVA, Aliandra Bittencourt; MACHADO, Regimar Carla. Elaboração de guia teórico de atendimento em parada cardiorrespiratória para enfermeiros. Rev Rene, v.14, n.4, p.1014-1021, 2013. Disponível em:

http://www.periodicos.ufc.br/rene/article/view/3641/2883. Acesso em: 12 jun. 2018.

SILVA, Karla Rona, et al. Parada cardiorrespiratória e o suporte básico de vida no ambiente pré-hospitalar: o saber acadêmico. Saúde (Santa Maria), v.43, n.1, p.53-59, 2017. Disponível em:

https://periodicos.ufsm.br/revistasaude/article/view/22160/pdf. Acesso em: 09 jun. 2018.

TODESCATO, Dicélia Lourenço Neto, et al. Proposta de protocolo em reanimação em parada cardiorrespiratória: uma análise a partir de três protocolos. Rev Cient FACUnicamps, v.9. n.1, p.1-16, 2017. Disponível em: http://www.unicampsciencia.com.br/pdf/59977cafd2791.pdf. Acesso em: 09 jun. 2018. 